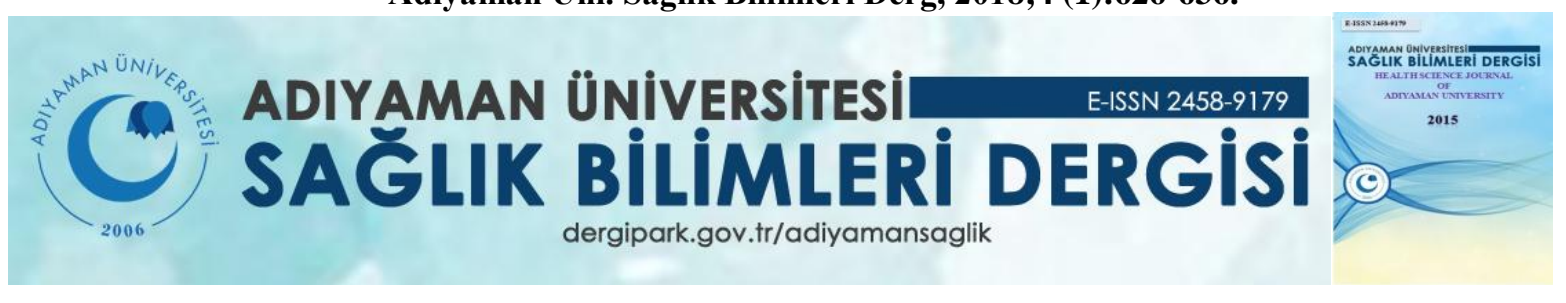

\title{
Araștırma/Research
}

\section{Non-spesifik Kas Ağrısı Olan Hastalarda Serum Vitamin D Düzeylerinin Yaş ve Cinsiyete Göre Dağılımı.}

\author{
Semra COŞKUN ${ }^{1}$, Onur KILINÇ ${ }^{1}$, Ayşe Atılgan ÇELİK ${ }^{1}$, Adem YILDIRIM $^{1}$ \\ ${ }^{1}$ :Adiyaman Üniversitesi Tıp Fakültesi, Fiziksel Tıp ve Rehabilitasyon Anabilim Dalı, Adıyaman, Türkiye
}

\section{Özet}

Amaç: Bu çalışmanın amacı non-spesifik kas ağrısı şikayeti ile başvuran hastalarda vitamin D eksiklik oranlarının belirlenmesini ve bu hasta grubunda serum vitamin D düzeyinin cinsiyet ve yaşa göre dağılımını incelemektir.

Yöntem: Çalışmada Ocak 2016 - Kasım 2017 tarihleri arasında polikliniğimize başvuran ve nonspesifik miyalji tanısı almış 2.832 hastadan, serum vitamin D düzeyi ölçülmüşs olan 188 hastanın verileri retrospektif olarak incelendi. Hastalar serum 25-hidroksivitamin D (25[OH]D) düzeyine göre 4 kategoriye ayrıldı [I- Ciddi eksiklik grubu ( $<10 \mathrm{ng} / \mathrm{ml}$ ), II- Eksiklik grubu ( $\geq 10$ ve $<20 \mathrm{ng} / \mathrm{ml}$ ), IIIYetersizlik grubu ( $\geq 20 \mathrm{ve}<30 \mathrm{ng} / \mathrm{ml}$ ) ve IV- Normal grup ( $\geq 30 \mathrm{ng} / \mathrm{ml})$ ]. Kadın ve erkeklerin yaş ve serum 25[OH]D düzeyi ortalamaları karşılaştırıldı. Yaş ile serum 25[OH]D düzeyi sonuçları arasındaki potansiyel ilişkinin varlığı ve yönünü değerlendirmek için korelasyon testleri yapıldı.

Bulgular: Çalışmaya dahil edilen 188 hastanın 170 tanesi kadın $(\% 90,4), 18$ tanesi erkekti $(\% 9,5)$. Kadın hastalarda ortalama serum 25[OH]D düzeyi $(11,61 \pm 5,40 \mathrm{ng} / \mathrm{ml})$, erkek hastalardan $(18,28 \pm 7,96$ $\mathrm{ng} / \mathrm{ml}$ ) istatistiksel olarak anlamlı düzeyde daha düşük olduğu saptandı. Hastaların 77 tanesi ciddi eksiklik grubunda $(\% 40,95), 91$ tanesi eksiklik grubunda $(\% 48,40), 14$ tanesi yetersizlik grubunda $(\% 7,44), 6$ tanesi de normal olan grupta $(\% 3,19)$ bulunuyordu. Yaş ile $25[\mathrm{OH}] \mathrm{D}$ düzeyi arasında anlamlı korelasyon saptanmadi.

Sonuç: Bu çalışma non-spesifik kas ağrısı şikayeti olan hastaların, yaklaşık \%90'ında vitamin D düzeyinin eksik veya ciddi eksik olduğunu göstermiştir. Bu nedenle, vitamin $\mathrm{D}$ eksikliği nonspesifik kas ağrısı ayırıcı tanısında göz önünde bulundurulmalı ve eksiklik veya yetmezlik durumlarında uygun replasman tedavi rejimleri uygulanmalıdır.

Anahtar kelimeler: Kas ağrısı, vitamin D, miyalji

Yazışmadan Sorumlu Yazar

Semra COŞKUN

Adıyaman Üniversitesi Tıp Fakültesi

Fiziksel Tıp ve Rehabilitasyon Anabilim Dalı

E-posta: semracoskun316@gmail.com
DOI:10.30569/adiyamansaglik.374988

\begin{tabular}{ll}
\hline Geliş Tarihi: & 04.01.2018 \\
\hline Kabul Tarihi: & 14.01.2018
\end{tabular}




\section{Distribution of vitamin D levels according to age and gender in patients with non- specific muscle pain.}

\section{Summary}

Aim: The aim of this study was to determine the rate of vitamin D deficiency in patients with non-specific muscle pain and to investigate the distribution of vitamin D levels according to gender and age in this group.

Material and methods: In this retrospective study, the data of 2.832 patients diagnosed as non-specific myalgia who applied to our polyclinic between January 2016 and November 2017 were examined and 188 patients whose vitamin D levels were measured were included the study. Patients were divided into 4 categories according to serum 25 [OH]D level [ISerious deficiency group ( $<10 \mathrm{ng} / \mathrm{mL}$ ), II- Deficiency group $(\geq 10$ to $<20 \mathrm{ng} / \mathrm{mL})$, IIIInsufficiency group ( $\geq 20$ to $<30-\mathrm{ng} / \mathrm{mL}$ ) and IV- Normal group ( $\geq 30 \mathrm{ng} / \mathrm{ml}$ )]. The mean age and serum $25[\mathrm{OH}] \mathrm{D}$ levels of women and men were compared. Correlation tests were performed to assess the presence and direction of the potential relationship between age and serum $25[\mathrm{OH}] \mathrm{D}$ levels.

Results: Of the 188 patients included in the study, 170 were female (90.4\%) and 18 were male $(9.5 \%)$. The mean serum 25[OH]D levels in female (mean $11.61 \pm 5.40 \mathrm{ng} / \mathrm{ml}$ ) were significantly lower than male patients (mean $18.28 \pm 7.96 \mathrm{ng} / \mathrm{ml}$ ). Of the patients, 77 were in the serious deficiency group (40,95\%), 91 were in the deficiency group (48,40\%), 14 were in the insufficiency group (7.44\%) and 6 were in the normal group (3.19\%). There was no significant correlation between age and 25[OH]D levels.

Conclusion: This study shows that in about $90 \%$ of patients with non-specific muscle pain complaints were deficient or serious deficient of vitamin D levels. Therefore, vitamin D deficiency should be considered in the differential diagnosis of non-specific myalgia and appropriate replacement therapy regimens should be applied in cases of deficiency or insufficiency.

Key words: muscle pain, vitamin D, myalgia 


\section{Giriş}

Vitamin D doğumdan ölüme kadar büyüme, gelişme ve sağlıklı bir iskelet yapısı için gerekli olan sekosteroid yapıda bir hormondur (1). Vücutta sentezlenebilen tek vitamin olma özelliğine sahiptir (2). Vitamin D başlıca deride 7-dehidrokolesterol'den üretilen steroid yapılı bir hormon olup vitamin D ihtiyacının \%95 kadarı güneş 1şınlarının etkisiyle deride sentezlenmektedir. Vitamin D'nin iki ana formu olup; deride sentezlenen formu kolekalsiferol (vitamin $\mathrm{D}_{3}$ ), besinlerle alınan formu ergokalsiferol (vitamin $\mathrm{D}_{2}$ )'dür (3). Ciltte ultraviyole 1şığın etkisiyle sentezlenen vitamin D3 önce karaciğerde hidroksillenir ve 25-hidroksivitamin D oluşur ve daha sonra 25[OH]D böbrekte tekrar hidroksilasyona uğrar ve metabolik olarak aktif form olan 1,25-dihidroksivitamin D oluşur (4). Kişide vitamin D düzeyinin normal veya eksik olduğunu anlamak için 25[OH]D düzeyine bakılmalıdır: Çünkü 25[OH]D yarı ömrü 2-3 hafta olan majör form olup hem vitamin D alımını ve hem de endojen yapımı göstermektedir. Ulusal ve uluslararası kılavuzların çoğunda 25[OH]D düzeyi; $20 \mathrm{ng} / \mathrm{ml}$ 'den düşük ise vitamin D eksikliğii, $20 \mathrm{ng} / \mathrm{ml}$ ve üstü ile $30 \mathrm{ng} / \mathrm{ml}$ arasında ise vitamin D yetersizliğii, $30 \mathrm{ng} / \mathrm{ml}$ ve üstü ise normal yani yeterli vitamin D düzeyi olarak kabul edilmektedir (5). 25[OH]D düzeyinin $150 \mathrm{ng} / \mathrm{ml}$ üzerinde olması durumunda ise Vitamin D intoksikasyonundan bahsedilir (6).

Vitamin D’nin temel görevi çocuklarda büyüyen kemik dokusunun, erişkinlerde ise kemik yeniden yapımı; mineralizasyonu için gerekli kalsiyum ve fosfor konsantrasyonunu idame ettirmektir (7). Başlıca etkilerini gösterdiği organlar böbrekler, ince barsaklar ve kemikler olup bu organlardaki etkilerini aktif formu olan kalsitriol tarafindan ortaya koyar. Son zamanlarda D vitamininin klasik olmayan etkilerinin araştırıldığı yayınlar ardı ardına bildirilmektedir. $\mathrm{Bu}$ çalışmalar sayesinde $\mathrm{D}$ vitamininin aktif formu olan kolekalsiferol reseptörü insan vücudunun birçok doku ve hücresinde tespit edilmiştir (8). Aktif D vitaminin 
temel görevi intestinal kalsiyum ve fosfor emilimini sağlayarak parathormon ile birlikte organizmanın kalsiyum/fosfor dengesini korumaktır. Vitamin D'nin hücre farklılaşması, proliferasyonu, anjiogenez ve apopitoz düzenlenmesinde rolü olduğu bilinmektedir ve eksikliğinin ise diyabetes mellitus, kanser, otoimmun, enfeksiyöz, endokrin hastalıklarla ve artmış kardiyovasküler mortalite ve morbidite ile ilişkisi bulunmaktadır (9). Dünyada 1 milyar kişide vitamin D eksikliği veya yetersizliği olduğu düşünülmekte olup özellikle de kuzey bölgelerinde yaşayanlar, koyu tenli kişiler, >70 yaş üstü erişkinler, geleneksel kapalı giyinen toplumlarda yaşayanlar, kapalı alanlarda bulunanlar, vücut kitle indeksi 30’un üstündeki kişilerin risk altında olduğu düşünülmektedir (5).

Vitamin D ve kas fonksiyonları arasında sıkı bir ilişki olduğu iyi bilinmektedir. İnsanlarda sağlıklı kas dokusunun idamesinde vitamin D’nin önemli rolü bulunmaktadır. Vitamin D eksikliğinin kas fonksiyonları üzerindeki en önemli ve ciddi klinik bulgusu proksimal kas güçsüzlüğüdür. Kaslarda diffüz ağrı, oturma ve merdiven çıkma hareketlerini yapmada zorlanma da diğer sık karşılaşılan bulgulardır (10).

Biz bu retrospektif çalışmada non-spesifik kas ağrısı tanısı almış hastaların vitamin D düzeylerini inceledik. Böylece miyalji tanılı hastalardaki vitamin D eksiklik oranlarının belirlenmesini ve bu hasta grubunda vitamin D düzeyinin cinsiyet ve yaşa göre dağılımını incelemeyi amaçladık.

\section{Gereç ve Yöntemler}

Çalışmamızda Ocak 2016 - Kasım 2017 tarihleri arasında hastanemiz Fiziksel Tıp ve Rehabilitasyon polikliniğine kas ağrısı şikayeti ile başvuran ve non-spesifik miyalji tanısı konmuş 2.832 hastadan vitamin D düzeyi ölçülmüş olan 188 hastanın verileri retrospektif olarak incelendi. Enfeksiyöz hastalığı bulunan, endokrin patolojisi olan, enflamatuvar 
romatizmal hastalık tanısı bulunan, antihiperlipidemik ilaçlar başta olmak üzere kas ağrısı yaptığı iyi bilinen ilaç kullanım öyküsü olanlar, miyopati tanısı almış hastalar ve eksiklik nedeniyle vitamin D replasman tedavisi alanlar çalışmaya dahil edilmedi.

Türk Endokrinoloji ve Metabolizma Derneği'nin 2017'de yayınladığı Osteoporoz ve Metabolik Kemik Hastalıkları Tanı ve Tedavi Kılavuzu'na (11) göre serum 25[OH]D düzeyine göre 4 kategoride değerlendirildi. I-Ciddi eksiklik grubu (vitamin D düzeyi $<10$ ng/ml olanlar), II- Eksiklik grubu (vitamin D düzeyi 11-20 ng/ml olanlar), III- Yetersizlik grubu (vitamin D düzeyi 21-30 $\mathrm{ng} / \mathrm{ml}$ olanlar) ve IV- Normal grup (vitamin D düzeyi >30 $\mathrm{ng} / \mathrm{ml}$ olanlar).

\section{Istatistiksel Analiz}

İstatistiksel analizlerde Windows için SPSS (ver. 18, SPSS Inc, Chicago Ill, USA) istatistik programı kullanıldı. Kategorik değişkenler yüzde olarak, sürekli değişkenler ortalama \pm standart sapma (minimum-maksimum) olarak gösterildi. Kadın ve erkeklerin yaş ve serum $25[\mathrm{OH}]$ vitD konsantrasyonu ortalamaları bağımsız değişkenler $\mathrm{t}$ testi ile karşılaştırıldı. Yaş ile serum $25[\mathrm{OH}]$ vitD konsantrasyonu sonuçları arasındaki potansiyel ilişkinin varlığı ve yönünü değerlendirmek için Pearson korelasyon testleri yapıldı. Tüm istatistiksel analizlerde anlamlılık düzeyi $\mathrm{p}<0.05$ olarak kabul edildi.

\section{Bulgular}

Çalışmaya dâhil edilen 188 hastanın 170 tanesi kadın $(\% 90,4), 18$ tanesi erkekti (\%9,5). Kadın hastaların yaş ortalaması 43,76 $\pm 16,73$ (18-90) yıl, erkek hastaların ise

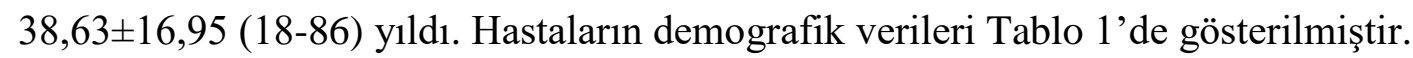




\section{Tablo 1: Hastaların demografik verileri}

\begin{tabular}{|c|c|c|c|c|c|c|}
\hline & & Sayı (N) & Ortalama & Standart Sapma & Minimum & Maksimum \\
\hline \multirow{3}{*}{$\underset{\pi}{\pi}$} & Kadın & 170 & 43,76 & 16,73 & 18 & 90 \\
\hline & Erkek & 18 & 38,63 & 16,95 & 18 & 86 \\
\hline & Toplam & 188 & 43,29 & 16,77 & 18 & 90 \\
\hline & $p^{*}$ & & 0,237 & & & \\
\hline
\end{tabular}

Kadın hastalarda serum vitamin D düzeyi ortalama $11,61 \pm 5,40 \mathrm{ng} / \mathrm{ml}$ iken erkek hastalarda $18,28 \pm 7,96 \mathrm{ng} / \mathrm{ml}$ idi. Vitamin D düzeyi ortalamasının kadın hastalarda istatistiksel olarak anlamlı düzeyde daha düşük olduğu saptandı $(\mathrm{p}<0,001)$. Hastaların serum vitamin D ölçüm sonuçlarının cinsiyete göre dağglımı Tablo 2'de verilmiştir.

\section{Tablo 2: Hastaların vitamin D ölçüm sonuçlarının cinsiyete göre dağılımı}

\begin{tabular}{|c|c|c|c|c|c|c|}
\hline & & Sayı (N) & Ortalama & Standart Sapma & Minimum & Maksimum \\
\hline \multirow{3}{*}{ 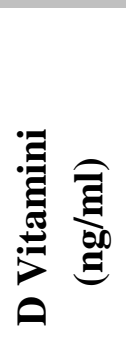 } & Kadın & 170 & 11,61 & 5,40 & 3,2 & 36,1 \\
\hline & Erkek & 18 & 18,28 & 7,96 & 8,8 & 32 \\
\hline & Toplam & 188 & 12,25 & 6,00 & 3,2 & 36,1 \\
\hline & $p^{*}$ & & $<0,001$ & & & \\
\hline
\end{tabular}

*: Kadın-erkek vitamin D ortalaması "bağımsıı değişkenler t testi” ile karşılaştırıldı. 
Hastaların 77 tanesi ciddi eksiklik grubunda (\%40,95), 91 tanesi eksiklik grubunda $(\% 48,40), 14$ tanesi yetersizlik grubunda $(\% 7,44), 6$ tanesi de normal olan grupta $(\% 3,19)$ bulunuyordu. Serum vitamin D ölçüm sonuçlarına göre gruplama Tablo 3'te gösterilmiştir.

\begin{tabular}{|c|c|c|c|c|c|}
\hline Grup & $\begin{array}{l}\text { Say1 } \\
\text { (N) }\end{array}$ & Ortalama & Standart Sapma & Minimum & Maksimum \\
\hline$<10 \mathrm{ng} / \mathrm{ml}$ & 77 & 7,31 & 1,72 & 3,2 & 9,8 \\
\hline 2. $\geq 10 \mathrm{ve}<20 \mathrm{ng} / \mathrm{ml}$ & 91 & 13,61 & 2,68 & 10 & 19,1 \\
\hline 3. $\geq 20$ ve $29 \mathrm{ng} / \mathrm{ml}$ & 14 & 22,19 & 2,31 & 20 & 26 \\
\hline$\geq 30 \mathrm{ng} / \mathrm{ml}$ & 6 & 31,93 & 2,25 & 30 & 36,1 \\
\hline
\end{tabular}

Korelasyon analizi sonucunda yaş ile vitamin D düzeyi ölçüm sonuçları arasında anlamlı ilişki olmadığı görüldü. Yaş ile vitamin D düzeyi ölçüm sonuçlarının korelasyon analizi Tablo 4'te; cinsiyete göre hasta yaşı ve serum vitamin D düzeyi dağılımı ise Şekil 1'de gösterilmiştir.

Tablo 4: Yaş ile vitamin D düzeyi ölçüm sonuçlarının korelasyon analizi

\begin{tabular}{ccc} 
& \multicolumn{3}{c}{ Vitamin D düzeyi } \\
\cline { 2 - 3 } & $\mathrm{r}$ & $p^{*}$ \\
Yaş & $\mathbf{- 0 , 1 0 8}$ & $\mathbf{0 , 1 4 1}$ \\
\hline
\end{tabular}

*:Pearson korelasyon analizi 


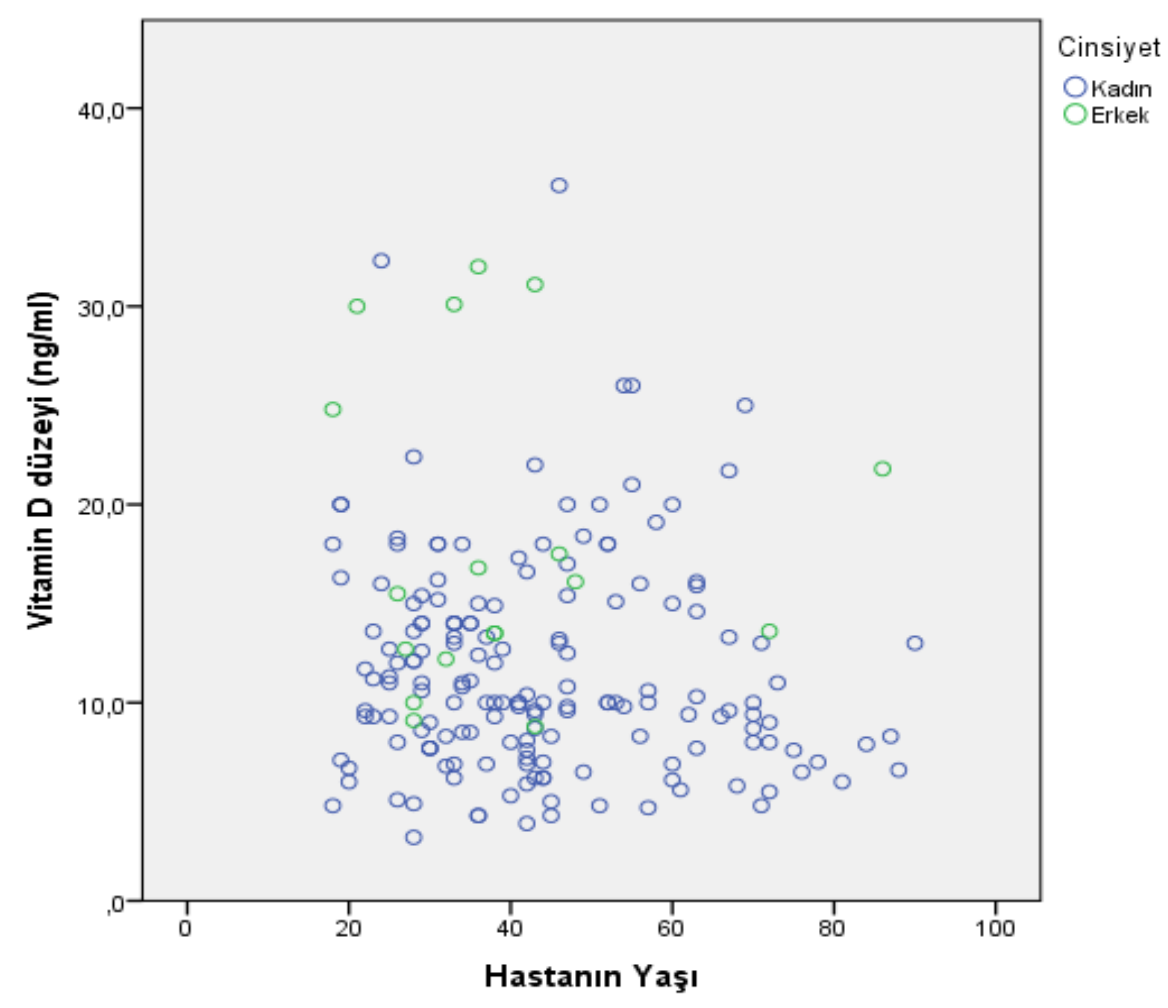

Şekil 1: Cinsiyete göre hasta yaşı ve serum vitamin D düzeyi dağılımı.

\section{Tartışma}

Vitamin D düzeyi eksikliği, kemik yapım-yıkım hızında artma, osteoporoz ve osteomalazi, diyabetes mellitus, hipertansiyon, kanser, otoimmun hastalıkların da yer aldığ kronik hastalıklar ve çoğu kalça kırı̆̆ı olmak üzere diğer kemiklerdeki kırık riski artışı gibi sorunlara yol açabilmesi nedenleriyle dünyada önemli bir sağlık problemi haline gelmiştir (1). Vitamin D eksikliğinin en belirgin bulgusu ağrıdır ve genellikle belden başlayıp, pelvis, kalça, sırt ve kostalara yayılır (12). Çidem ve ark. yaptıkları çalışmada yaygın kas-iskelet ağrısı olan hastalarda vitamin D eksikliği $(25[\mathrm{OH}]$ vitD $<20$ olanlar $)$ prevelansının \%71,7 olduğunu bildirmişlerdir (4). Bizim çalışmamızda vitamin D eksikliğinin daha yüksek oranda $(\% 89,36)$ saptanmasının nedeni çalışmaya alınan hastaların kişisel özelliklerine bağlı olabileceği gibi şikayetleri başladıktan sonra hastaneye başvurma süresindeki gecikmeye de bağlı olabilir. 
Diğer taraftan ağrı ile vitamin D eksikliğinin ilişkili olmadığını bildiren çalışmalar da mevcuttur. $\mathrm{Bu}$ yönde görüş bildiren Yener, ağrı ve vitamin $\mathrm{D}$ ilişkisini araştırdığ çalışmasında vitamin D ile kas-iskelet sistem semptomları arasında bir ilişki bulunmadığını belirtmiştir (13).

Hekimsoy ve ark. vitamin D eksikliğinin kadınlarda daha sık görüldüğünü belirtmişler (14). Benzer şekilde Kurt ve ark. da yaptıkları çalışmalarında vitamin D düzeyi ile cinsiyet arasında anlamlı ilişki olduğunu ve kadınlarda vitamin $\mathrm{D}$ düzeylerinin daha düşük olduğunu bildirmişlerdir (15). Bizim çalışma sonuçlarımız, kas ağrısı tanısı almış hasta grubuna yönelik olması nedeniyle vitamin D eksikliğinin cinsiyete göre sıklığını belirtmekten uzak olsa da, her iki cinsiyete ait ortalama serum vitamin D düzeyleri bu konuda bir fikir verebilir. Çalışma verilerimize göre serum vitamin D düzeyi ortalaması kadın hastalarda, erkek hastalardan anlamlı olarak daha düşük bulunmuştur. Cinsiyetler arası görülen bu fark, kadınların kültürel giyinme alışkanlıklarına bağlı olarak güneş ışığından daha az yararlanması nedeniyle olabilir (16). Diğer taraftan bu konuda yapılan bir çalışmada ise Uçar ve ark. 25[OH]D düzeyi açısından cinsiyetler arası anlamlı farklılık bulamamışlardır (17).

Vitamin D düzeyinin yaş ile ilişkisini inceleyen bir çalışmada Kurt ve ark. anlamlı ilişki saptayamamışlardır (15). Benzer şekilde bizim çalışmamızda da yaş ile vitamin D düzeyi ölçüm sonuçları arasında anlamlı korelasyon saptanmadı. Diğer taraftan literatürde vitamin D eksikliğinin yaşlı popülasyonda daha sık görüldüğünü bildiren çalışmalar ağırlık kazanmaktadır (18). Bunun sebebi olarak da ilerleyen yaşla birlikte bağırsaklardan kalsiyum ve vitamin D emilimi ile böbreklerden aktif vitamin D oluşumu azalması, yaşlanmayla birlikte güneş ışınlarının alımında ve diyetle vitamin $\mathrm{D}$ alımında azalma, derinin $\mathrm{D}$ vitamini sentezleme becerisinde yaşla birlikte gözlenen azalma olduğu gösterilmiştir (19). 
Çalışmamızın en önemli kısıtlılığı retrospektif bir çalışma olmasıdır. Hastaların tanı ve takip veri kayıtlarının ayrıntılı olmaması nedeniyle, başlangıç ağrı düzeyini belirleyen objektif parametrelerin olmaması, vitamin D replasmanı sonrası şikayetlerde düzelme olup olmadığının bilinmemesi, eğitim düzeyi, menopoz durumu, ilaç kullanımı, çevresel faktörler, aktivite durumu vb. gibi parametrelerin çalışmaya yansıtılamaması çalışmanın diğer önemli kısıtlılıklarını oluşturmaktadır.

\section{Sonuç}

Bu çalışma non-spesifik kas ağrısı şikayeti olan hastaların yaklaşık \%90'ında vitamin D düzeyinin eksik veya ciddi eksik olduğunu göstermiştir. Bu nedenle Vitamin D eksikliği non-spesifik kas ağrısı ayırıcı tanısında göz önünde bulundurulmalı ve eksiklik veya yetmezlik durumlarında uygun replasman tedavi rejimleri uygulanmalıdır.

\section{Kaynaklar}

1. Öğüş E, Sürer H, Kılınç A, Fidanı V, Yılmaz G, Dindar M, Karakaş A. D Vitamini Düzeylerinin Aylara, Cinsiyete ve Yaşa Göre Değerlendirilmesi. Ankara Medical Journal 2015;15(1):1-5.

2. Yavuz D, Mete T, Yavuz R, Altunoğlu A. D Vitamini, Kalsiyum\&Mineral Metabolizması, D Vitaminin İskelet Dışı Etkileri ve Kronik Böbrek Yetmezliğinde Nutrisyonel D Vitamini Kullanımı. Ankara Medical Journal 2014;14(4):162-171.

3. Kıdır V. D Vitamininin kardiyovasküler ve metabolik etkileri. Journal of Clinical and Experimental Investigations 2013;4(3):398-404.

4. Çidem M, Kara S, Sarı H, Özkaya M, Karacan İ. Yaygın Kas-İskelet Ağrısı Olan Hastalarda D Vitamini Eksikliği Prevalansı ve Risk Faktörleri. Journal of Clinical and Experimental Investigations 2013;4(4):488491.

5. Öngen B, Kabaroğlu C, Parıldar Z. D Vitamininin Biyokimyasal ve Laboratuvar Değerlendirmesi. Türk Klinik Biyokimya Dergisi 2008;6(1):23-31.

6. Holick MF. Vitamin D deficiency. The New England Journal of Medicine. 2007;357:266-281 
7. Akpınar P, İçağasığlu A. D Vitamininin Yaşam Kalitesi ile İlişkisi. Türk Osteoporoz Dergisi 2012;18:13-18.

8. Genç A, Gülmez Sevim D, Tok Özen A, Yılmaz G. D Vitamininin Çeşitli Hastalıklardaki Nadir Kullanım Alanlar1. Journal Of Ankara University Faculty of Medicine 2015;68(2):55-60.

9. Sarıfakıoğlu B, Akçay Yalbuzdağ Ş, Yıldırım Güzelant A, İkbali Af̧̧ar S, Ustaömer K. D Vitamini ile İlişkili Kas-İskelet Sistemi Bulguları. Türk Osteoporoz Dergisi 2015;21:113-117.

10. Özkan B, Döneray H. D vitamininin iskelet sistemi dışı etkileri. Çocuk Sağllğı ve Hastalıkları Dergisi 2011;54:99-119.

11. Yavuz DG, Akalın A, Alış M et al. Bölüm 13: Vitamin D Eksikliği. Osteoporoz ve Metabolik Kemik Hastalıkları Tanı ve Tedavi Kılavuzu (Türkiye Endokrinoloji ve Metabolizma Derneği) 2017:119-127

12. Kaya Ü, Karadağ Saygı E, Akyüz G. Yaşlı Kadınlarda D Vitamini Tedavisinin Ağrı ve Yaşam Kalitesi Üzerine Etkileri. Türk Osteoporoz Dergisi 2010;16(1):9-12.

13. Yener M. Kas iskelet sistem ağrısı ile vitamin $\mathrm{D}$ düzeyleri arasındaki ilişkinin araştırılması. SDÜ Tlp Fakültesi Dergisi 2007;14(4):7-11.

14. Hekimsoy Z, Dinç G, Kafesciler S, Onur E, Güvenç Y, Pala T, Güçlü F, Bilgin Ö. Vitamin D status among adults in the Aegean region of Turkey. BMC Public Health 2010;10(1):782.

15. Kurt M, Cömertoglu İ, Sarp Ü, Yalçın P, Dinçer G. Osteoporozlu Hastalarda D Vitamini Düzeyleri. Türk Osteoporoz Dergisi 2011;17(3):68-70.

16. Aypak C, Yıkılkan H, Dicle M, Önder Ö, Görpelioğlu S. Erişkin Obez Hastalarda D Vitamini Düzeyinin Vücut Kitle İndeksi ile İlişkisi. The Medical Bulletin of Haseki 2013;51:95-98.

17. Uçar F, Yavuz Taş̧ıpınar M, Özden Soydaş A, Özcan Nurgül. Ankara Etik İhtisas Eğitim ve Araştırma Hastanesine Başvuran Hastalarda 25-OH Vitamin D Düzeyleri. European Journal of Basic Medical Sciences 2012;2(1):12-15.

18. Walker-Bone K, Dennison E, Cooper C. Epidemiology of osteoporosis. Rheumatic Disease Clinics of North America 2001;27(1):1-18.

19. Sarıdoğan M, Akarırmak Ü, Eskiyurt N, Tüzün Ş, İrem Örnek N. Türkiye'nin 3 Farklı Coğrafi Bölgesindeki Postmenopozal Kadınlarda D Vitamini ve Kemik Mineral Yoğunluğunun Korelasyonu. Türk Osteoporoz Dergisi 2010;16(3):49-52. 